\title{
特集「シカの採食圧による植生被害防除と回復」
}

\section{ニホンジカ高密度生息域のススキ草原における草原生 植物種多様性の低下}

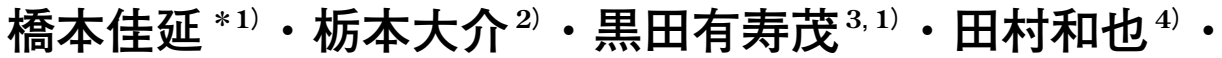 \\ 福井 聡 ${ }^{5}$
}

1）兵庫県立人と自然の博物館自然 - 環境再生研究部 Division of Ecological Restoration, Museum of Nature and Human Activities, Hyogo

2）財団法人ひょうご環境創造協会 Hyogo Environmental Advancement Association

3）兵庫県立大学自然 - 環境科学研究所 Institute of Natural and Environmental Sciences University of Hyogo

4）株式会社 里と水辺研究所 Institute of Rural \& Urban Ecology Co., LTD.

5）一般財団法人 日本気象協会 Japan Weather Association

\begin{abstract}
摘要 : 良好に管理されているススキ草原の種多様性がシカの採食によって受ける影響を明らかにするために, シ 力高密度化が進む兵庫県神河町の砥峰高原ススキ草原にて防鹿柵を設置し, 柵内外の出現種の出現頻度 - 平均被 度を調查した。結果, ススキ以外の草本種種数は防鹿柵区の方が約 4 種多かった $(\mathrm{p}<0.05)$ 。ススキ以外の草本 植物被度は防鹿柵区で 4.0 ポイント高く $(\mathrm{p}<0.05)$, 広葉草本被度は防鹿柵区の方が 4.9 ポイント高かった（p $<0.001$ ）。防鹿柵区での平均被度が有意に高い種（種群 $\mathrm{A} ）$ は 2 種, 防鹿柵のみに出現した種（種群 $\mathrm{B} ）$ は 8 種 確認された。防鹿柵と無柵区との間に生じる広葉草本の被度の差違への寄与率は種群 $\mathrm{A}$ が $27 \%$, 種群 B が 11 \%だった。このことから，シカの採食はススキ草原の種多様性に対して負の影響をもたらし，その影響は特定の 種に対して顕著に及ぶ可能性があると考えられた。シカの高密度生息地域では，管理により良好に維持されてい るススキ草原であっても，シカの採食により植物の種多様性が低下する恐れがある事が示唆された。 キーワード : ススキ群落, 防鹿柵, 砥峰高原, 植物被度, 出現種数
\end{abstract}

HASHIMOTO, Yoshinobu, TOCHIMOTO, Daisuke, KURODA, Asumo, TAMURA, Kazuya and FUKUI, Satoshi: Reduction in grassland plant species diversity of a Miscanthus sinensis community in an area of high sika deer density

Abstract To clarify the impact of sika deer (Cervus nippon Temminck) browsing on the diversity of grassland plant species in a well-maintained Miscanthus sinensis community in a high-density area of sika deer, we established deer-proof fences in a $M$. sinensis community and surveyed the occurrence and coverage of each species inside and outside the fences in the town of Kamikawa, Hyogo Prefecture. The number of grassland plant species excluding $M$. sinensis, the total coverage of grassland plants excluding $M$. sinensis, and the total coverage of forb plants were significantly lower outside the fences than inside. Similarly, the coverage of both species was significantly lower outside the fences than inside. Eight species grew only inside the fences. These species disproportionately occurred inside the fences and contributed a total of $33 \%$ of the total coverage of forb plants inside the fences. These findings suggest that browsing by sika deer has had a negative impact on the species diversity of the $M$. sinensis community. In particular, our findings suggest that browsing has a potentially negative impact on several specific species. M. sinensis-dominated grassland maintained in good condition is at risk of losing its species diversity through sika deer browsing in areas of high sika deer density.

Key words: grassland plant species, Miscanthus sinensis community, Cervus nippon Temminck, deer-proof fence, species diversity 


\section{1.はじめに}

近年, 国内各地でニホンジカCervus nippon Temminck の 生息密度が上昇し，全国規模での植生の衰退が懸念されてい る ${ }^{20)}$ 。これまで報告されているシカの過食圧による植生衰退 の事例は植物群落の種組成・構造の変化 ${ }^{2.3}$, 種多様性の変 化 ${ }^{3,9,19)}$, 構成種の被度の低下 ${ }^{23,25)}$ や個体数の減少・消失な ど22, 24,25)が挙げられる。これらの報告の大半は森林群落にお けるものであり, 被害報告の約 9 割が森林群落といわれ $る^{20)}$ 。ところが，草原植生，特にススキが優占する大規模草 原（以下，ススキ草原）に扔けるシ力食害についての研究事 例は少なく ${ }^{13)}$ ， ススキの喏好性が低いこと ${ }^{1)}$ あって森林に 比べシカ食害の影響が外観に現れにくく，その植生衰退の害 態については十分に検討されていない。

ススキ草原は, 土地改変, 管理放異に伴う遷移の進行など により面積が激減し ${ }^{7}$ ，急速に失われつつある ${ }^{8}$ 。また残さ れたススキ草原においても種組成が変化して ${ }^{111}$, 草原生植物 の多くが絶滅の危機に瀕している。そのため, 全国各地のス スキ草原では，希少種を含む草原生植物を中心とした生物多 様性の保全を目的に刈り取りや火入れなどの管理活動が行わ れている ${ }^{12)}$ 。しかし，良好な管理により維持されるススキ草 原であったとしても地域のシカが高密度化した場合にはその 食害の影響をうけるおそれがある。

ススキ草原は, 草原生の絶滅危惧植物の生育にとって重要 な生態系であり，地域の生物多椂性を保全するためには， シ カによる影響を把握することが急務といえる。そこで本研究 では, 近年のシカの高密度化が報告される兵庫県神河町砥峰 高原ススキ草原において，防鹿柵を設置，防鹿柵内外の植生 の変化を調査しシカ食害による種多様性への影響を明らかに したので報告する。

\section{2. 方 法}

\section{1 調查地概要}

調查地は兵庫県神河町砥峰高原で, 標高 800 850 $\mathrm{m}$ の範 囲に位置し, 瀬戸内気候地域よりも降水量多い内陸気候地域 に属している17)。

本草原は戦前より行われている毎年 1 回の早春の火入れ によってススキ草原として維持されており ${ }^{100}$, 貴重な植物群 落（群落複合）のAランクに指定される ${ }^{6}$ 保全上重要な生態 系である。本草原は, ホクチアザミ, リンドウ, ツリガネニ ンジン, ミッバツチグリ, ヤマハギ, ゼンマイ, アキノキリ ンソウ, シラヤマギク, ニガナ, オトコヨモギ, チゴユリ, オオアブラススキなどを構成種として含むことから，ススキ 一ホクチアザミ群集に同定されている ${ }^{18)}$ 。なお，植物の学名 は表-1に示した。

本地域の 2008 年に扔けるシカの出猟 1 人 1 日当たりの目 撃頭数は 2 3 頭/人・日で, 周辺と比較して相対的に值が 高く, シカの生息密度は高( ${ }^{4)}$ 。砥峰高原周辺のスギ・ヒノ キ林でのシカによる樹皮摂食は 1982 年には確認され，年を

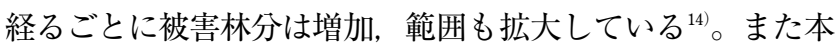

地域ではシカの生息数は 2004 年〜2008 年にかけて 5 20\% の増加 ${ }^{4}, 2006$ 年〜2010 年にかけては $20 \%$ 以上の増加 ${ }^{5}$ が 報告されており，少なくとも 1980 年代から本地域でのシカ の生息密度は増加傾向にあると考えられる。砥峰高原の火入 れ管理を実施する兵庫県神河町川上地区の住民および，との みね自然交流館へのヒアリングによれば，近年，ススキ草原 内の草原生植物の個体数や種数が減少, ススキの穂の密度や 草丈が低下しており, シカの食害による植生衰退の可能性が 懸念されている。

\section{2 方形区設置}

シカの食害によるススキ群落の種多様性への影響を検証す るため, 草原内に防鹿柵区 $(8 \mathrm{~m} \times 8 \mathrm{~m})$ および無柵区 $(8 \mathrm{~m}$ $\times 8 \mathrm{~m} ）$ を各 3 区設置した。各区内には植生調查用の小方形 区 $(2 \mathrm{~m} \times 2.5 \mathrm{~m})$ を 5 区（合計 30 区）設置した。方形区は 火入れ後の 2010 年 4 月に, 防鹿柵は 2010 年 5 月に設営し た。

\section{3 植生調查}

調査は 2010 年 9 月に実施した。調査では小方形区ごとに 出現する全植物種の被度（\%）を測定した。立地環境につい ては斜面方位，傾斜角度をクリノメーターにて計測した。

無柵区と防鹿柵区との種組成の比較のため, 各区における 出現種の出現頻度および平均被度を算出し, 総出現回数 2 回以上の種を対象に, 出現頻度および平均被度の無柵区と防 鹿柵区間の差違についての検定を行い，その結果を考慮し て，次のようなグループに分類した。すなわち，「無栅区(防 鹿柵区）で被度が有意に高い種」「「無柵区（防鹿柵区）で出 現頻度が有意に高い種」，「無柵区（防鹿柵区）の久に出現し た種」の 6 種群と, これらにあてはまらない種の「その他 の種」とに分類した。検定方法については次項に表記した。

種多様性の比較のため, 小方形区ごとに総出現種数および 草本種の出現種数 (以後, 草本種種数と示す) と被度合計值 （全種，ススキ以外の草本種，広葉草本）を算出した。

\section{4 統計解析}

小方形区ごとの総出現種数, 草本種種数, 被度合計值 (全 種, ススキ以外の草本種, 広葉草本) と, 無柵区と防鹿柵区 に打ける各出現種の平均被度, 出現頻度について防鹿柵の有 無の効果を検証するために, 各柵区をランダム効果として一 般化線形混合モデルを用いて分析した。なお, 確率分布はポ ワソン分布, リンク関数は対数リンクとした。統計解析には R（ver. 3.0.0, パッケージ glmmML) ${ }^{15}$ を用いた。

\section{3. 結 果}

調査では全方形区をあわせて 58 種が確認された。確認さ れた種群（表-1）は, 防鹿柵区で平均被度が有意に高い種群 ( 2 種 : アキノキリンソウ, クロバナヒキオコシ), 防鹿柵 区のみで出現した種群（8種：サワヒヨドリ，スズサイコ， ノギラン, ムカゴソウ, ゼンマイ, ヤブレガサ, ウメバチソ ウ, オオアブラススキ), 防鹿柵区で欠落した種群（1 種： クリ）の 3 種群で, 無柵区で出現頻度または平均被度が有 意に高い種はみられなかった。 


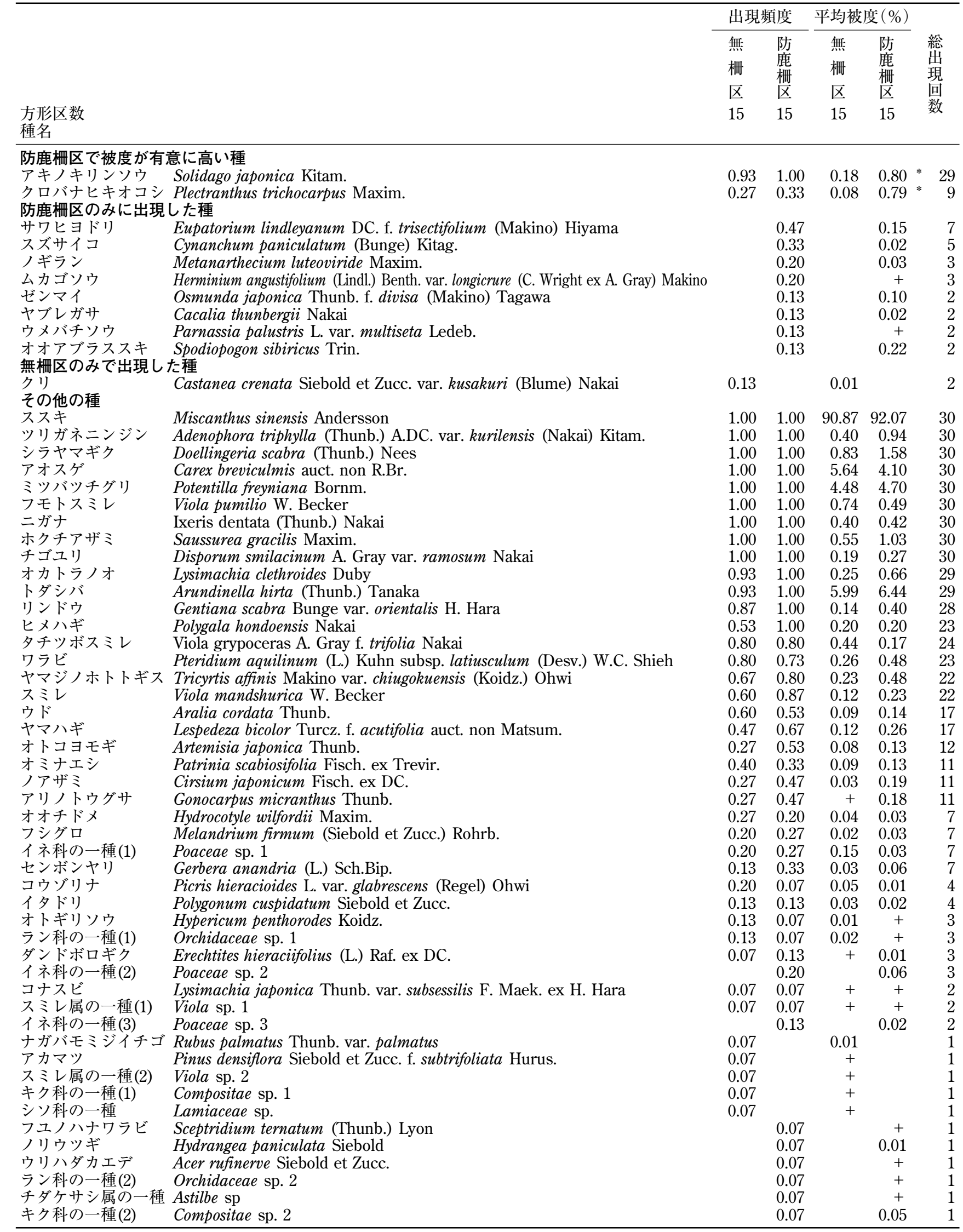

* : $\mathrm{p}<0.05,+$ : 平均被度が $0 \%$ よりきく $0.01 \%$ 未満であることを示す。 
表-2 無柵区と防鹿柵区における平均出現種数と平均被度合計

\begin{tabular}{|c|c|c|c|c|c|c|}
\hline \multirow{3}{*}{\multicolumn{2}{|c|}{$\begin{array}{l}\text { 調査区数 } \\
\text { 変数 }\end{array}$}} & \multirow{2}{*}{\multicolumn{2}{|c|}{$\begin{array}{c}\text { 無柵区 } \\
15\end{array}$}} & \multicolumn{3}{|c|}{ 防鹿柵区 } \\
\hline & & & & \multicolumn{2}{|c|}{15} & \\
\hline & & Ave. & $\mathrm{SD}$ & Ave. & $\mathrm{SD}$ & \\
\hline \multirow[t]{2}{*}{ 種数 } & 全種 & 20.7 & 2.50 & 24.7 & 2.55 & $*$ \\
\hline & 草本種のみ & 20.4 & 2.16 & 24.5 & 2.50 & $*$ \\
\hline \multirow{3}{*}{$\begin{array}{l}\text { 被度 } \\
(\%)\end{array}$} & 全種の合計 & 112.8 & 9.67 & 118.2 & 12.39 & \\
\hline & $\begin{array}{l}\text { ススキ以外の草 } \\
\text { 本種の合計 }\end{array}$ & 21.8 & 8.34 & 25.8 & 11.10 & $*$ \\
\hline & 広葉草本の合計 & 10.0 & 5.18 & 14.9 & 9.46 & $* * *$ \\
\hline
\end{tabular}

*** : $\mathrm{p}<0.001,{ }^{* *}: \mathrm{p}<0.01, * \mathrm{p}<0.05$ であることを示す。

優占種についてみると，防鹿柵区，無㒳区のいずれにおい てもススキが最も優占しており，防鹿柵区では $92.07 \%$ ，無 柵区では $90.87 \%$ と 1.2 ポイントの差がみられたが統計的に 有意ではなかった。

表-2に無柵区と防鹿畘区における平均出現種数および平 均被度を示した。平均出現種数をみると, 全種については無 柵区で 20.7 種, 防鹿柵区で 24.7 種と防鹿柵区の方が 4 種多 かった（p<0.05）（表-2）。また，草本種のみについては無 梱区で 20.4 種, 防鹿柵区で 24.5 種と防鹿柵区の方が 4.1 種 多かった（p<0.05）（表-2）。

平均被度をみると, 全種の合計については無柵区で 112.8 \%，防鹿柵区で $118.2 \%$ と，防鹿柵区の方が 5.4 ポイント高 かったが統計的に有意ではなかった（表-2）。一方，ススキ 以外の草本植物の合計については無柵区で $21.8 \%$, 防鹿柵 区で $25.8 \%$ と防鹿柵区で 4.0 ポイント高く $(\mathrm{p}<0.05)$, 広 葉草本の被度合計については，無柵区で $10.0 \%$, 防鹿㒳区 で $14.9 \%$ と防鹿柵区の方が 4.9 ポイント高く統計的に有意 であった（p<0.001）（表-2）。広葉草本の中でも，特にアキ ノキリンソウとクロバナヒキオコシの被度は防鹿柵区のほう 高かった（各 0.62 ポイント, 0.71 ポイント)。広葉草本の合 計の差に対するこれら 2 種の寄与率は $27 \%$ で, これらと防 鹿柵区のみに出現した広葉草本 5 種をあわせてみた寄与率 は $33 \%$ であった。

\section{4. 考察}

本研究の結果から，防鹿柵の設置によって出現種数，特に 草本種の出現種数が多くなること，ススキ以外の草本種の被 度合計, 広葉草本の被度合計が増加することが認められた

(表-2)。防鹿柵区，無柵区の優占種であるススキの平均被 度被度は $90 \%$ 以上と高く, 両区間での差違もわずかであっ

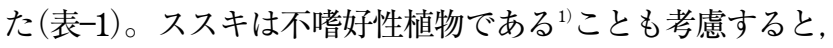
シカの採食により優占種の被度が変化し，そのことによって 優占種下層の光環境や空間配置などが変化してススキ以外の 草本植物の生育状況に間接的に影響が及ぶとは考えにくい。 そのため, 草本植物の出現頻度や被度の変化はシカの採食の 直接的な影響による可能性が高いと考えられる。草食獣の採 食圧と種多様性の関係については，大津ほか ${ }^{14}$ がシカの草原
利用頻度が比較的低い地域では種数が増加する傾向にある が，ある程度より高い地域となると種数が減少する傾向があ ることを示している。また坂上 ${ }^{16}$ は，家畜の放牧圧と草原の 種多様性の関係について, 軽度の放牧で種多様性が高まり, 過度の放牧で種多様性が低下することを報告している。これ らのことから，本草原でのシカの採食圧は種多様性を低下さ せる程度に高いと考えられる。

平均被度については, 防鹿柵の設置によってススキ以外の 草本種の被度合計, 広葉草本の被度合計が増加することが認 められた（表-2）。また，防鹿柵区で平均被度が有意に高い 傾向を示したのは 2 種であった（表-1）。防鹿柵区と無柵区 の広葉草本の平均被度合計の差は 4.9 ポイントで, そのうち $33 \%$ は，防鹿柵内で被度が有意に高い種および，柵内のみ で出現した種に占められていた。また防鹿柵のみに出現した 8 種をあわせた場合の寄与率は $11 \%$ を占めていた。このこ とは, シカの採食によるススキ草原の草原生植物に対する負 の影響は 2 つのグループのように特定の種に及んでいる可 能性を示している。また，その影響は，アキノキリンソウや クロバナヒキオコシのように強い影響を受けるものと, サワ ヒヨドリ，スズサイコのように弱い影響を受けるものという ように種によって影響が異なる可能性があることも示唆され た。しかし，種ごとに受ける影響の強弱の解明には，より広 範で中長期的な調査が必要であると考えられる。

\section{5. おわりに}

ススキ草原における植物の種多様性の低下については管理 放棄に伴う遷移の進行が主たる原因として認識されてきた。 本研究の結果, シカの生息密度の高い地域では, 管理により 良好な状態が維持されているススキ草原であっても, シカの 採食により植物の種多様性が低下する可能性が示唆された。 そのため, 今後はススキ草原の種多様性低下の要因としてシ カの食害についても考慮する必要があるといえる。本研究で は防鹿柵設置期間が 1 シーズンと短かったため, より詳細 な影響については長期間の防鹿柵設置による植生の変化のモ ニタリングによって明らかにする必要がある。しかし, 森林 群落におけるシカ食害の事例が示すようにシカ生息密度の上 昇によりその影響は短期間に生じるおそれがある。したがっ て, 保全の優先順位の高いススキ草原については防鹿柵の設 置やシカの生息密度管理などを先行して実施し, 予防的な観 点から保全対策を進めていく必要があるといえる。

謝辞 : 本研究を実施するにあたり, 現地調査では神戸大学大 学院人間発達環境科学研究科修士の日下石碧氏, 前川恵美子 氏, 道本久美子氏, 神戸大学発達科学部学生の塩谷智也氏, 永田優子氏, 神戸女学院大学の田丸真奈維氏, (財)ひょうご 環境創造協会の諸井郁子氏, 野口香澄氏に多大なるご協力を いただきました。ここに厚くお礼申し上げます。また防鹿柵 の設営・撤去についてはとのみね自然交流館館長の草部利光 氏, 神河町川上地区区長の藤原幸夫氏, 兵庫県農政環境部環 境創造局自然環境課自然公園係，神河町役場の皆様のご協力 
をいただきました。この場を借りてお礼申し上げます。

なお本研究には, (財)国際科学技術財団 2010 年度助成研 究掞よび平成 23 年度科学研究費補助金若手研究 B (課題番 号：23701026）の一部を使用しました。

\section{引用文献}

1）安藤行雄（2012）シカの被害が分かる図鑑，（財）日本森林 林業振興会熊本支部, $161 \mathrm{pp}$.

2）藤木大介・鈴木 牧 - 後藤成子・横山真弓 - 坂田宏志 (2006) ニホンジカ（Cervus nippon）の採食下にある旧薪 炭林の樹木群集の構造について, 保全生態学研究, 11: 2134 .

3）服部 保 - 栃本大介 - 南山典子 - 橋本佳延 - 藤木大介 - 石 田弘明（2010）宮崎県東諸県郡綾町川中の照葉原生林にお けるニホンジカの採食の影響, 植生学会誌, 27: 35-42.

4) 兵庫県 (2010) 第 3 期シ力保護管理計画（第 2 次変更）, 兵庫県, $27 \mathrm{pp}$

5）兵庫県（2012）第 4 期シ力保護管理計画，兵庫県， $24 \mathrm{pp.}$

6）兵庫県農政環境部環境創造局自然環境課（2010）兵庫の貴 重な自然 兵庫県版レッドデータブック 2010 （植物・植物 群落), (財)ひょうご環境創造協会, $217 \mathrm{pp}$.

7）岩波悠生（1995）我が国草原の現状と課題，国立公園，534: 2-5.

8）環境省自然環境局（編）（2004）日本の植生 II 第 5 回自 然環境保全基礎調査報告書（全国版），(財)自然環境研究 センター, $346 \mathrm{pp}$.

9）大橋春香 - 星野義延 - 大野啓一 (2007) 東京奥多摩地域に おけるニホンジカ（Cervus nippon）の生息密度増加に伴う 植物群落の種組成変化, 植生学会誌, 24: 123-151.

10）大河内地点自然環境調查団・(株) 新日本技術コンサルタン 卜（1978）大河内地点自然環境実態調査報告書, 208 pp.

11）大窪久美子 (1998）7. 半自然草原の自然保護, 沼田真編, 自然保護ハンドブック，朝倉書店, pp. 432-468.

12）大澤雅彦 (監修), 日本自然保護協会（編）（2001）生態学 からみた身近な植物群落の保護，講談社， $244 \mathrm{pp}$.

13）大津千晶・星野義延・末崎 朗（2011）秩父多摩甲斐地域 を中心とする山地帯・亜高山帯草原に与えるニホンジカの 影響, 植生学会誌, 28: 1-17.
14）尾崎真也（2004）兵庫県におけるニホンジカによるスギ壮 齢林の樹皮摂食害の害態, 森林応用研究 13: 69-73.

15) R Core Team (2013) R: A language and environment for statistical computing g. R Foundation for Statistical Computing, Vienna, Austria.

URL http://www.R-project.org/.(参照 : 2013. 4. 3)

16）坂上清一（2001） ススキ草地植生の長期的傾向：20 年間 の野外観測, 日本草地学会誌, 47: 430-435.

17）坂田 正（1995）兵庫県の気候，橋本光正編，兵庫県の樹 木誌, 兵庫県農林水産部局林務課豊かな森づくり推進室, pp. 384-388.

18）菅沼孝之（1976）我が国に扔けるススキ草原の群落分類体 系, 平吉功先生退官記念事業会編, ススキの研究, 平吉功 先生退官記念事業会, pp. 29-44.

19） Suzuki, M., Miyashita, T., Kabaya, H., Ochiai, K., Asada, M. and Tange, T. (2008) Deer density affects ground-layer vegetation differently in conifer plantations and hardwood forests on the Boso Peninsula, Japan. Ecol. Res., 23: 151158.

20）植生学会企画委員会（2011）ニホンジカによる日本の植生 への影響—シカ影響アンケート調査 (2009〜2010) 結果一, 植生情報, 15: 9-96.

21) Takatsuki, S. (1977) Ecological studies about effect of Sika deer (Cervus nippon) on vegetation I. Evaluation of grazing intensity of Sika Deer on the Vegetation in Kinkazan Island, Japan, Ecol. Review 18: 233-250.

22) Takatsuki, S. and Gorai, T. (1994) Effects of Sika deer on the regeneration of a Fugus crenata forest on Kinkazan Island, northern Japan. Ecol. Research, 9: 115-120.

23）田村 淳（2007） ニホンジカの採食圧を受けてきた冷温帯 自然林における採食圧排除後 10 年間の下層植生の変化, 森林立地，49: 103-110.

24) Tsujino, R. and Yumoto, T. (2004) Effects of sika deer on tree seedlings in a warm temperature forest on Yakushima Island, Japan. Ecol. Res., 19: 291-300.

25）蒲谷 肇（1988）東京大学千葉演習林荒樫沢における常緑 広葉樹林の下層の変化とニホンジカの食害による影響，東 大農学部演習林報告, 78: 67-82.

(2013. 11. 13 受理) 